\title{
New locality of arsenical copper in chili
}

\section{Von Zinken}

To cite this article: Von Zinken (1838) New locality of arsenical copper in chili, Philosophical Magazine Series 3, 12:73, 217-217, DOI: 10.1080/14786443808649412

To link to this article: http://dx.doi.org/10.1080/14786443808649412

册 Published online: 01 Jun 2009.

Submit your article to this journal $x$

III Article views: 3

Q View related articles $₫$ 
strongly heated, so much so that it is necessary to surround the receiver with cold water to prevent the reconversion of it into carbonate of potash. The saturation is complete when it ceases to give out heat. It is then dissolved in the smallest possible quantity of water at the temperature of $100^{\circ}$ to $120^{\circ} \mathrm{Fahr}$; ; upon the cooling of the filtered solution, the greater part of the bicarbonate separates in fine crystals.-Poggendorff's Annals.

\section{NEW LOCALITY OF ARSENICAL COPPER IN CHILI, BY VON ZINKEN.}

Amongst some Chilian minerals from San Antoni6, near Copiapo, was some massive native silver, accompanied by a tin-white substance, which, when broken, has somewhat the appearance of copper pyrites; this locality also furnishes native copper, native silver containing copper, polybarite, and calcareous spar. The fracture of this new mineral is uneven; it occurs tabular, kidney-shaped, and massive; it scratches calcareous spar, but is scratched by fluor spar and a knife; its specific gravity is not easily determined, as it is always accompanied by native silver. Exposed to heat in an open tube, it gives out arsenious acid, then a white vapour, (oxide of antimony?); upon increasing the heat it is converted into a red scoriaceous mass, which attacks the glass, and imparts to it the colour of oxide of copper; the fumes also smell of sulphureous acid. The roasted mineral fused with soda gives a button of copper not containing silver. Melted with borax, it gives a red and yellow scoriaceous mass, and a bead of copper. It is acted upon violently by nitric acid, which dissolves it, leaving a black flocculent residue recognisable as sulphur, mixed with a little arsenic. This mineral is therefore a compound of arsenic, sulphur, antimony, and copper, and is somewhat similar to condurrite, an arsenical copper found at Condurrow, near Camborne, Cornwall --Poggendorff's Annals, vol. 41, p. 392.

\section{DEFINITE COMBINATION OF OXIDE OF SILVER AND OXIDE OF LEAD, BY PROF. WGEHLER.}

When a salt of silver is contained in a solution of a salt of lead, caustic alkali throws down a yellow precipitate,-a reaction which is of great interest in analytical chemistry. This yellow precipitate is insoluble in excess of caustic alkali; but by digestion in the latter, any free oxide of lead precipitated with it may be separated. This yellow substance, according to analysis, is a combination of 1 equivalent of oxide of silver, and 2 equivalents of oxide of lead; and 100 parts consist of $34 \cdot 23$ oxide of silver, and $65 \cdot 77$ oxide of lead. Upon exposure to the light it turns black. Upon heating to redness it gives a mixture of metallic silver and oxide of lead. In hydrogen gas it is reduced to an alloy with a very gentle heat. . It is easily soluble in nitric acid.

In a mixture of a salt of silver with a salt of protoxide of manganese, a caustic alkali throws down a black precipitate. This appears to be a very intimate mixture of metallic silver with peroxide of manganese. It is dissolved by acids without the disengagement of any gas, 